\title{
INDÚSTRIA DE CELULOSE E O AVANÇO DA SILVICULTURA DO EUCALIPTO NA FRONTEIRA AGRÍCOLA DA AMAZÔNIA MARANHENSE
}

Allison Bezerra Oliveira ${ }^{1}$

Resumo: Este trabalho tem por objetivo apresentar o processo recente de avanço da silvicultura do eucalipto na fronteira agrícola da Amazônia Legal maranhense. Considera-se a reprodução de modelos históricos de apropriação e mercantilização da área por grandes projetos econômicos mínero-agro-exportadores, em especial, o aumento de áreas de plantio de eucalipto decorrente da implantação de unidade fabril da Suzano Papel e Celulose no município de Imperatriz, estado do Maranhão, em 2009. Quanto à metodologia, além de produção cartográfica e mapeamento da cadeia produtiva de papel e celulose e sua dinâmica no Maranhão, são apresentados dados relativos à evolução da monocultura do eucalipto. Os dados obtidos sugerem a reprodução do modelo histórico de economia de enclave, perpetrado pelos grandes empreendimentos agroextrativistas na Amazônia, voltados para a produção de commodities de exportação a partir da pilhagem irrestrita de recursos naturais com pouco retorno socioeconômico local.

Palavras-chave: Silvicultura do eucalipto. Fronteira agrícola. Amazônia Legal. Imperatriz - MA.

\section{CELLULOSE INDUSTRY AND THE PROGRESS OF EUCALYPTUS SILVICULTURE ON THE AGRICULTURAL BORDER OF MARANHENSE AMAZONIA}

Abstract: This paper has as the main goal present the recent evolution of the eucalyptus silviculture over the agriculture border of Legal Amazon in the State of Maranhão. It's considered the propagation of historical appropriation and commodification models of the area by large economical projects based on oreagriculture-export, specially, the increase of the eucalyptus plantation due to the installation of the plant from the company Suzano, Paper and Cellulose in the city of Imperatriz, Maranhão State, in 2009. The methodology is to present the cartographic production and the productive chain of the paper and cellulose over the Maranhão State, we present data regarding the evolution of the eucalyptus monoculture plantation. The data obtained suggest the reproduction of the historical model of enclave economy, perpetrated by the large agroextractivist ventures in the Amazon, aimed at the production of export commodities from the unrestrained plundering of natural resources with little local socioeconomic return.

Keywords: Eucalyptus silviculture. Agricultural frontier. Legal Amazonia. Imperatriz MA.

\footnotetext{
1 Universidade Estadual da Região Tocantina do Maranhão - UEMASUL, Centro de Ciências Humanas Sociais e Letras - CCHSL, Grupo de Pesquisas Socioeconômicas do Maranhão - GPS, Imperatriz, Brasil, allisonbzr@gmail.com, http://orcid.org/0000-0003-0320-5661
} 


\section{INDUSTRIA DE CELULOSA Y EL AVANCE DE LA SILVICULTURA DEL EUCALIPTO EN LA FRONTERA AGRÍCOLA DE LA AMAZONIA MARANHENSE}

Resumen: Este trabajo tiene por objetivo presentar el proceso reciente de avance de la silvicultura del eucalipto en la frontera agrícola de la Amazonia Legal maranhense. Se considera la reproducción de modelos históricos de apropiación y mercantilización del área por grandes proyectos económicos mínero-agroexportadores, en especial, el aumento de áreas de plantación de eucalipto resultante de la implantación de unidad fabril de Suzano Papel e Celulose en el municipio de Imperatriz, en el año 2009. En cuanto a la metodología, además de producción cartográfica y mapeamiento de la cadena productiva de papel y celulosa y su dinámica en Maranhão, se presentan datos relativos a la evolución del monocultivo del eucalipto. Los datos obtenidos sugieren la reproducción del modelo histórico de economía de enclave, perpetrado por los grandes emprendimientos agroextractivistas en la Amazonia, volcados a la producción de commodities de exportación a partir del saqueo irrestricto de recursos naturales con poco retorno socioeconómico local.

Palabras clave: Silvicultura del eucalipto; Frontera agrícola. Amazonia Legal. Imperatriz - MA.

\section{Introdução}

O processo de formação territorial do Brasil constituiu-se intimamente a partir de ciclos econômicos desencadeados por países do Hemisfério Norte, ciclos baseados majoritariamente na pilhagem de recursos naturais instituída desde 0 período colonial. Nesse contexto, desenvolveu-se um histórico padrão econômico voltado para a exportação que, desde então, é a motivação dominante para a ocupação das regiões brasileiras, em especial a Amazônia Legal.

Para Becker (1985, 1999, 2001, 2005, 2007), essa dominância está vinculada ao fato de a ocupação do território que hoje compreende a Amazônia, o Brasil e toda a América Latina constituir um episódio do amplo processo de expansão marítima das empresas comerciais europeias, o que, ao longo dos anos, levou esses territórios a se constituírem em algumas das mais antigas periferias da economia do mundo capitalista. Forjaram-se no paradigma sociedade-natureza, denominado "economia de fronteira", para o qual o progresso corresponde a crescimento econômico e prosperidade infinitos, via exploração de recursos naturais vistos como ilimitados.

Constituiu-se, assim, uma forma de estrutura produtiva baseada na compreensão equivocada da capacidade de (re)produção de recursos naturais em níveis ilimitados no Brasil. E, desse modo, foram desencadeadas ao longo dos anos ações de ocupações regionais baseadas no estabelecimento de fronteiras 
econômicas, em grande parte agroextrativistas, voltadas para a produção de commodities de exportação, consolidando o Brasil como país agroexportador.

No bojo dessas questões, está a porção da Amazônia Legal maranhense que pode ainda ser considerada a mais importante área de fronteira agrícola nordestina. Tal porção territorial tem consolidado, sobretudo a partir do século XX, um modelo de desenvolvimento regional baseado em projetos de reestruturação produtiva, promovidos pelas políticas econômicas de industrialização, baseadas especialmente na implantação de grandes projetos mínero-agro-exportadores.

Em especial, destaca-se o processo recente de implantação da unidade fabril da Suzano Papel e Celulose no município de Imperatriz, no estado do Maranhão, a partir de 2009. Tal implantação, abordada por Oliveira et al (2018), Oliveira (2018) e Oliveira e Nascimento (2018), representa os grandes e históricos projetos de reestruturação produtiva segundo modelos industriais de base agroextrativista.

A análise aqui apresentada destaca a atividade industrial da Suzano e sua implantação a partir da inserção do Maranhão na Amazônia Legal, e, com isso, a constituição de uma fronteira agrícola de base florestal. Pontua, ainda, os processos de desindustrialização ocorridos nos últimos anos em países do Hemisfério Norte, o que têm ocasionado a transferência de processos iniciais da cadeia produtiva de papel e celulose, os mais onerosos do ponto de vista socioambiental (e com menor valor agregado), para países periféricos, como o Brasil, constituindo modelos de desenvolvimento desigual e combinado do mundo capitalista (SMITH, 1988; HARVEY, 2005, 2013; PERPETUA et al, 2017; OLIVEIRA et al, 2018).

Dessa forma, o presente trabalho tem por objetivo apresentar o processo recente de avanço da silvicultura do eucalipto na fronteira agrícola da Amazônia Legal maranhense, desencadeado pela implantação da Suzano Papel e Celulose na região. E, como consequência, discutir as formas de apropriação dos recursos naturais destinados para a transformação em commodities.

Metodologicamente, faz-se comparativo entre os modelos históricos e atuais de crescimento econômico baseado na "economias de fronteira" estabelecidos no Maranhão. Paralelamente, é realizada mapeado processos recentes de desconcentração produtiva regional das unidades fabris de celulose no Brasil, da cadeia produtiva de papel e celulose no Maranhão, e das vantagens geográficas competitivas do estado para a atividade econômica em questão. Além de acervo fotográfico do processo produtivo em curso, é feito levantamento de municípios maranhenses produtores de eucalipto, além de dados secundários relativos à 
evolução de hectares destinados à silvicultura do eucalipto no Brasil e no Maranhão, extraídos do Instituto Brasileiro de Geografia e Estatística (IBGE) e da Indústria Brasileira de Árvores (IBÁ).

Além desta introdução e das considerações finais, o presente trabalho está dividido em quatro seções. Na primeira, "a fronteira agrícola na Amazônia Legal maranhense e a mercantilização da natureza", discute-se a constituição do conceito de "fronteira agrícola", à luz da abordagem de Becker (1985), e o processo de formação da Amazônia Legal maranhense nesta perspectiva; em "da gênese da indústria de papel e celulose no Brasil à implantação do grande empreendimento Suzano no município de Imperatriz - MA" busca-se apresentar a origem e o desenvolvimento da indústria de papel e celulose no Brasil frente ao seu processo recente de desconcentração industrial e implantação no município de Imperatriz. Nas seções seguintes, "cadeia produtiva do papel e celulose e sua dinâmica no Maranhão" e "o avanço da fronteira agrícola da silvicultura do eucalipto na Amazônia maranhense", aborda-se o desenvolvimento dessa cadeia no estado e discute-se os dados da pesquisa.

\section{A fronteira agrícola na Amazônia Legal maranhense e a mercantilização da natureza}

É fundamental compreender o processo territorial de formação socioeconômica do Maranhão a partir de modelos históricos de ocupação baseados em ciclos econômicos e expansão das fronteiras regionais. Nesse sentido, a inserção desse território no bioma amazônico e na constituição territorial da Amazônia Legal é uma característica a ser destacada. Dessa forma,

\footnotetext{
deve-se considerar a especificidade geográfica da integração do estado do Maranhão na composição da Amazônia Legal. Ocupando uma posição de transição entre três macrorregiões brasileiras (Norte, Nordeste e CentroOeste), a porção amazônica maranhense abrange uma área equivalente a $80 \%$ da superfície territorial do estado $(264 \mathrm{mil} \mathrm{km})$, a oeste do meridiano 44 W1, compreendendo 180 dos seus 217 municípios, distribuídos em cinco mesorregiões e 21 microrregiões. (MESQUITA et al, 2015, p. 227).
}

Assim, a própria história do Maranhão se confunde em muitos momentos com a da Amazônia Legal, que, conforme apresentado na Figura 1, abrange nove estados do Brasil: Acre, Amapá, Amazonas, Mato Grosso, Pará, Rondônia, Roraima, Tocantins e uma parte do estado do Maranhão. 


\section{Figura 1 - Amazônia Legal brasileira}

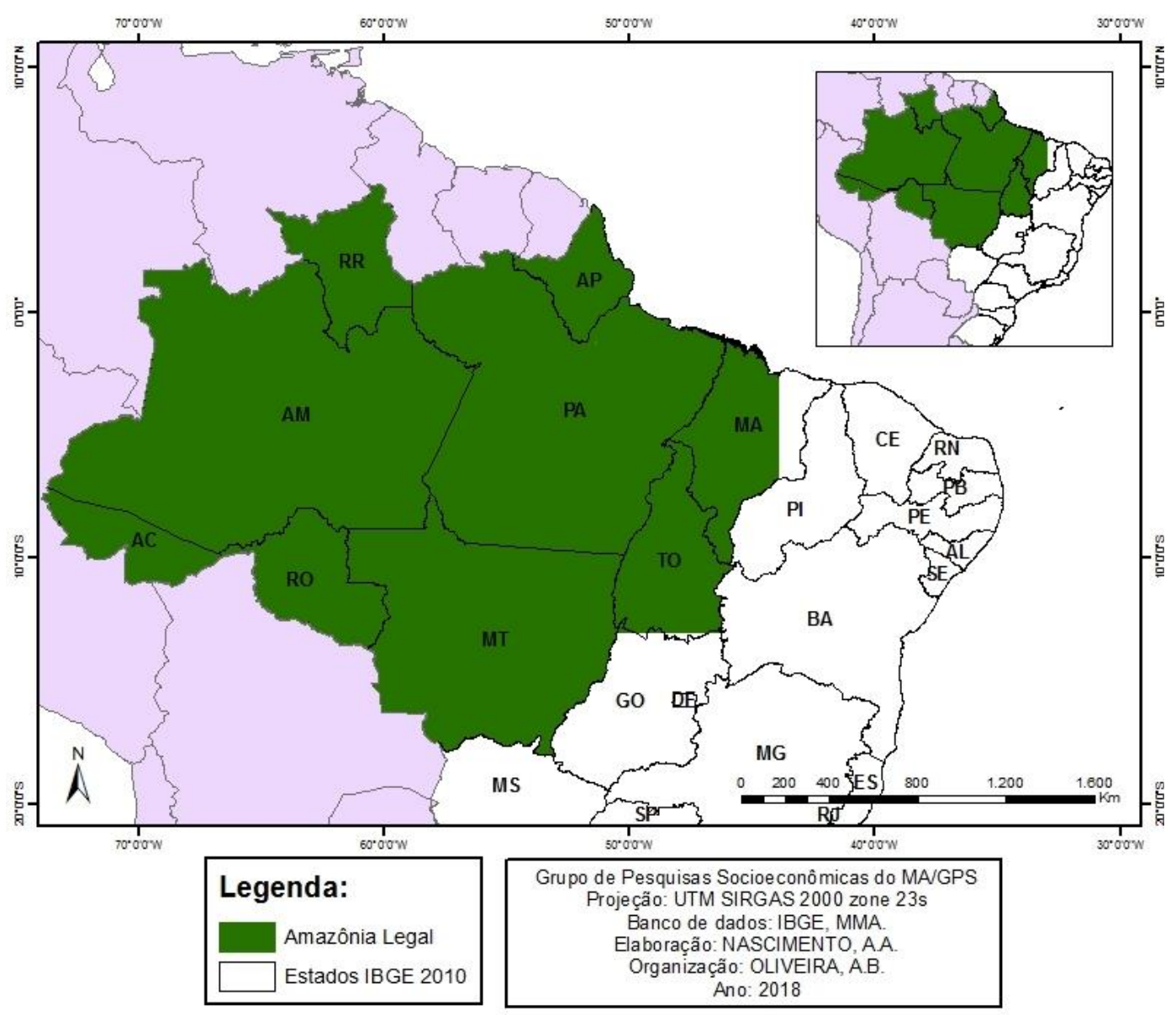

Fonte: Dados de pesquisa (2018)

Considerando a especificidade do Maranhão frente a esta delimitação, é fundamental entender que o processo de ocupação amazônico é longo e remete à própria constituição do Brasil, sendo, assim, fortemente atrelado a ciclos econômicos impulsionados por dinâmicas externas ou ondas de "integração" nacional. A Amazônia Legal é, portanto, delimitada em meio a processos de constituição de áreas de "integração" regional e fronteiras agrícolas, expropriação de recursos, grilagem de terras e conflitos socioambientais amparados fortemente pela ação estatal.

Aqui, consideramos a constituição da Amazônia Legal frente à construção de uma fronteira agrícola fruto de um processo de extrema mercantilização da natureza, e, como afirma Becker (2007), influenciada pela ação estatal dos governos de Getúlio Vargas e Juscelino Kubitschek, com projetos como o programa "Marcha para o Oeste", iniciado em 1938, e rodovias de penetração nacional, como a BR-010 ou Rodovia Belém-Brasília. 
Para fins de administração, instituíram-se os limites da Amazônia Legal definindo as linhas básicas do desenvolvimento regional. Foi criada também a Superintendência do Plano de Valorização Econômica da Amazônia (SPVEA), com base em discursos governamentais que se propunham a diminuir as desigualdades regionais, assegurar a ocupação da Amazônia, valorizar o território amazônico e promover o desenvolvimento da região e sua integração ao restante do país.

Ao final da década de 1950, os investimentos estatais do governo JK provocaram a demanda crescente por matérias-primas e alimentos, possibilitando a rápida integração da economia do Maranhão ao mercado brasileiro por meio da divisão nacional do trabalho. Em 1959, a Lei no 3.692 instituiu a Superintendência de Desenvolvimento do Nordeste (Sudene), cujos objetivos eram planejar a economia, buscar o crescimento econômico e reduzir as disparidades inter-regionais que persistiam apesar do crescente processo de industrialização.

Mas é somente entre 1966 e 1985 que se inicia o planejamento regional
efetivo da região. O Estado toma para si a iniciativa de um novo e ordenado
ciclo de devassamento amazônico, num projeto geopolítico para a
modernização acelerada da sociedade e do território nacionais. Neste
projeto, a ocupação da Amazônia assume prioridade por várias razões. É
percebida como solução para as tensões sociais internas decorrentes da
expulsão de pequenos produtores do Nordeste e do Sudeste pela
modernização da agricultura. Sua ocupação também foi percebida como
prioritária em face da possibilidade de nela se desenvolverem focos
revolucionários. (BECKER, 2007, p. 26).

Com o objetivo de agilizar o processo de ocupação da região, foi extinta a SPVEA e criada a Superintendência do Desenvolvimento da Amazônia (Sudam), em 1966, através da Lei no 5.173, de 27 de outubro de 1966, mantendo os limites territoriais da Amazônia Legal. A Sudam atuou principalmente na atração de investimentos para a Amazônia por meio do Fundo de Investimento da Amazônia (Finam) e dos incentivos fiscais (SODRÉ; RAMIRES, 2018).

Iniciou-se a partir daí a consolidação da expansão de uma fronteira econômica na Amazônia Legal iniciada pelo Maranhão, que implicou o avanço da ocupação e incorporação de novas áreas agrícolas no processo produtivo nacional, sobretudo no que tange à produção de matéria-prima. Determinou-se, ainda,

o fortalecimento da integração da economia local à das regiões CentroOeste e Sul do país e ao mercado exterior. Estes dois fatores estão articulados, grosso modo, à dinâmica econômica imposta pelo capital nacional e transnacional sediado nas regiões Sul e Sudeste, as mais desenvolvidas do país (MESQUITA et al, 2015, p. 227). 
Para Becker (1985), a fronteira agrícola é um espaço não estruturado plenamente, cuja definição considera reservas de recursos, sobretudo naturais, e espaço para manobra política e ideológica, destacando o viés desenvolvimentista que prevê a expansão do capital em áreas naturais ou de culturas preexistentes, gerando conflitos pelo uso e posse da terra e dos recursos naturais.

Diante disso, o povoamento da região e os processos econômicos de desenvolvimento fundamentaram-se no paradigma da relação sociedade-natureza, calcados em uma economia de fronteira, ou seja, o crescimento econômico é visto como linear e ilimitado, baseado na contínua incorporação de terra e de recursos naturais, que, embora finitos, são percebidos como ilimitados (BECKER, 1999, 2005).

Dessa forma, a ação estatal, aliada ao grande capital, converteu a Amazônia em fronteira do capital natural em nível global, num cenário de atração de grandes empreendimentos, grilagem de terras e conflitos agrários. O padrão de exploração, historicamente, constituiu-se da produção de grande quantidade de recursos naturais para o centro-sul do país e de commodities para o mercado externo.

Esse processo, intensificado na fronteira agrícola da Amazônia Legal brasileira, ativou, nos últimos anos, cada vez mais a mercantilização da natureza através da expropriação de recursos naturais. As atividades daí oriundas estão diretamente ligadas ao uso da terra e oferecem pouco retorno socioeconômico, pois além de concentradoras, são direcionadas para a produção majoritária de commodities agrícolas para o mercado externo, implicando pouco dinamismo regional-local.

Como no passado, esses empreendimentos mínero-agro-exportadores ou voltados para a indústria de transformação, assim como ocorria nos ciclos econômicos, instalam-se no território amazônico sob o discurso desenvolvimentista. Com os processos de desconcentração da indústria de celulose no Brasil, e, especificamente, a implantação da Suzano Papel e Celulose na cidade de Imperatriz, no estado do Maranhão, não tem sido diferente.

\section{Da gênese da indústria de papel e celulose no Brasil à implantação do grande empreendimento Suzano no município de Imperatriz - MA}

A busca pela consolidação da atividade industrial brasileira é, historicamente, um dos grandes gargalos produtivos do Brasil. Quando utilizamos o termo "consolidar", incorporamos sua perspectiva mais ampla: a de construção de aparato industrial com capital e tecnologia nacional e com capacidade tecnológica 
competitiva em consonância com as questões ambientais locais. Essa e outras debilidades contribuíram ao longo dos anos para a acentuação da divisão internacional do trabalho que nos colocou como um país quase que totalmente agroexportador.

Tal modelo produtivo agroexportador gera processos intensos de expropriação de grupos sociais, recursos naturais e, sobretudo, provoca um desenvolvimento desigual (SMITH, 1988) em que tem como resultado a manutenção do Brasil como periferia econômica mundial. Tal desenvolvimento desigual combina globalmente países "de primeiro mundo" com foco em atividades produtivas em processos de maior capacidade tecnológica e, consequentemente, maior valor agregado e menor impacto nos recursos naturais. E "do outro lado" países como o brasil focados em atividades do setor primário, com grande ônus ambiental e menor retorno econômico.

Em outras palavras, essa característica marcante da economia brasileira - a agroexportação - ditou, ao longo dos anos, ciclos econômicos, políticas de crescimento econômico e integração nacional. Isso pode ser compreendido à medida que se verifica a constituição de ciclos econômicos baseados na produção de commodities voltadas quase que exclusivamente para o mercado externo: paubrasil, açúcar, ouro, algodão, café, e, mais recentemente, soja e eucalipto.

Nesse contexto, o processo de industrialização do Brasil aconteceu de forma lenta, iniciando-se com o desenvolvimento da cultura cafeeira, cujos lucros passaram a financiar investimentos em outros setores econômicos, seguido do desenvolvimento tecnológico na produção de energia e de uma pequena malha ferroviária para transporte das sacas até o litoral. A produção de energia, à época baseada na queima de carvão, passou a ser elétrica, contribuindo para concentração industrial na região Sudeste e gerando declínio nas produções de açúcar e borracha nas regiões Norte e Nordeste, que dependiam da energia do carvão (CANO, 1986; SUZIGAN, 2000).

Com uma economia dependente do modelo agroexportador até metade do século $X X$, o Brasil enfrentou problemas econômicos e políticos, explodindo em 1929 a grande crise do setor voltado para o mercado de exportação. Os choques adversos (SUZIGAN, 2000) obrigaram o país a diversificar sua produção interna, ocasionando o crescimento da indústria brasileira. Foi no então governo de Getúlio Vargas (1930-1945) que a indústria nacional passou a ser incentivada a fim de acabar com sua dependência do mercado externo e conseguir suprir as demandas 
internas. Foram criadas leis protecionistas para o setor e investimentos na infraestrutura do país, fazendo com que o setor secundário começasse a crescer. Entretanto, esse desenvolvimento ainda era restrito à região Sudeste.

Dados os desequilíbrios regionais resultantes da concentração da pouca atividade industrial brasileira, em sua maioria de capital estrangeiro, iniciou-se ainda no final dos anos 1950 uma incipiente desconcentração produtiva regional do Brasil, pautada na integração nacional, na busca pela ocupação de "vazios" no país, na geração de emprego, abertura de mercados, e, especialmente, no fornecimento e beneficiamento de matérias-primas. A construção da Zona Franca de Manaus ${ }^{2}$ é o principal ponto de partida desse processo, que se acelerou a partir da década de 1970, com a criação de expressivos incentivos fiscais, sobretudo no Norte e Nordeste, atraindo novas unidades industriais para outras regiões do país (CANO, 2007b).

Mediante o avanço lento da industrialização brasileira, a relação estabelecida com o setor primário fez com que a indústria de bens de capital pouco avançasse no país, tendo seu foco na indústria de transformação, pautada no beneficiamento de matéria-prima para exportação. Sob a égide dessas particularidades, a indústria de papel e celulose no Brasil começou a se desenvolver tardiamente. A instalação dessas indústrias só começa a ocorrer em 1830 e seu desenvolvimento torna-se mais evidente em 1920, graças aos incentivos fiscais do governo (SUZIGAN, 2000).

A produção inicial era diretamente vinculada à demanda da Companhia Paulista de Estradas de Ferro, entretanto, após 1966 - por meio da Lei ํㅡㄴ.106, de 02 de setembro de 1966 - houve incentivos fiscais para a atividade de reflorestamento, gerando um aumento da área de plantio de 500 mil para 3 milhões de hectares, iniciando, assim, o cultivo do eucalipto em escala econômica (SUZIGAN, 2000).

Entretanto, nessa época o país importava praticamente todo o papel de imprensa que consumia, assim como certos papéis de qualidade especial, e ainda dependia largamente de importações de pasta de madeira para a produção interna de papel (SUZIGAN, 2000). Também segundo o autor, a indústria buscou fontes alternativas para produção de celulose, através da empresa Companhia Melhoramentos de São Paulo. Considerada a primeira fábrica de papel instalada em São Paulo, em 1883, ela passou a investir em pesquisas de espécies vegetais

\footnotetext{
${ }^{2}$ A Zona Franca de Manaus foi criada pelo Decreto-lei no 3.173, de 6 de junho de 1957, e melhorada dez anos depois pelo Decreto-lei no 288, de 28 de fevereiro de 1967.
} 
nativas do país, sob a supervisão de engenheiros agrônomos e florestais contratados na Europa.

Outra grande companhia estabeleceu-se no Brasil no período da Primeira Guerra Mundial: Klabin Irmãos \& Companhia, instalada em 1910. Foi a primeira a possuir máquinas para produção de pasta de madeira, e, em 1940, já era a maior indústria de papel e celulose do país, produzindo papel impresso à base de pinhodo-paraná. Contudo, nos primeiros anos da guerra, a indústria de papel sofreu grandes baixas pela escassez de matéria-prima, fazendo com que se utilizassem trapos, papel velho e palha de arroz, ou seja, itens recicláveis como alternativa para produção. Outro problema era a falta de proteção tarifária, assim como as dificuldades de logística: acesso a transporte e matéria-prima. Além disso, as indústrias produziam apenas papel de embrulho e papelão nas tonalidades marrom ou cinza, considerado uma produção grosseira. Portanto, não havia perspectiva de progresso para essa indústria, já que ela não conseguia produzir produtos de qualidade superior (SUZIGAN, 2000).

Para resolver esse problema, o governo passou a incentivar a produção de celulose com a isenção de impostos de importação sobre máquinas e insumos para empresas cuja finalidade fosse produzir celulose. No país, até 1930, só havia notícia de quatro fábricas de pasta, que utilizavam pinho, bambu, papel velho e fibras nativas como matéria-prima. Após esse período, a partir de pesquisas de laboratório, seguiu-se a descoberta do eucalipto como alternativa rentável de matéria-prima. 
Figura 2 - Grandes conglomerados industriais de papel e Celulose no Brasil em 2018

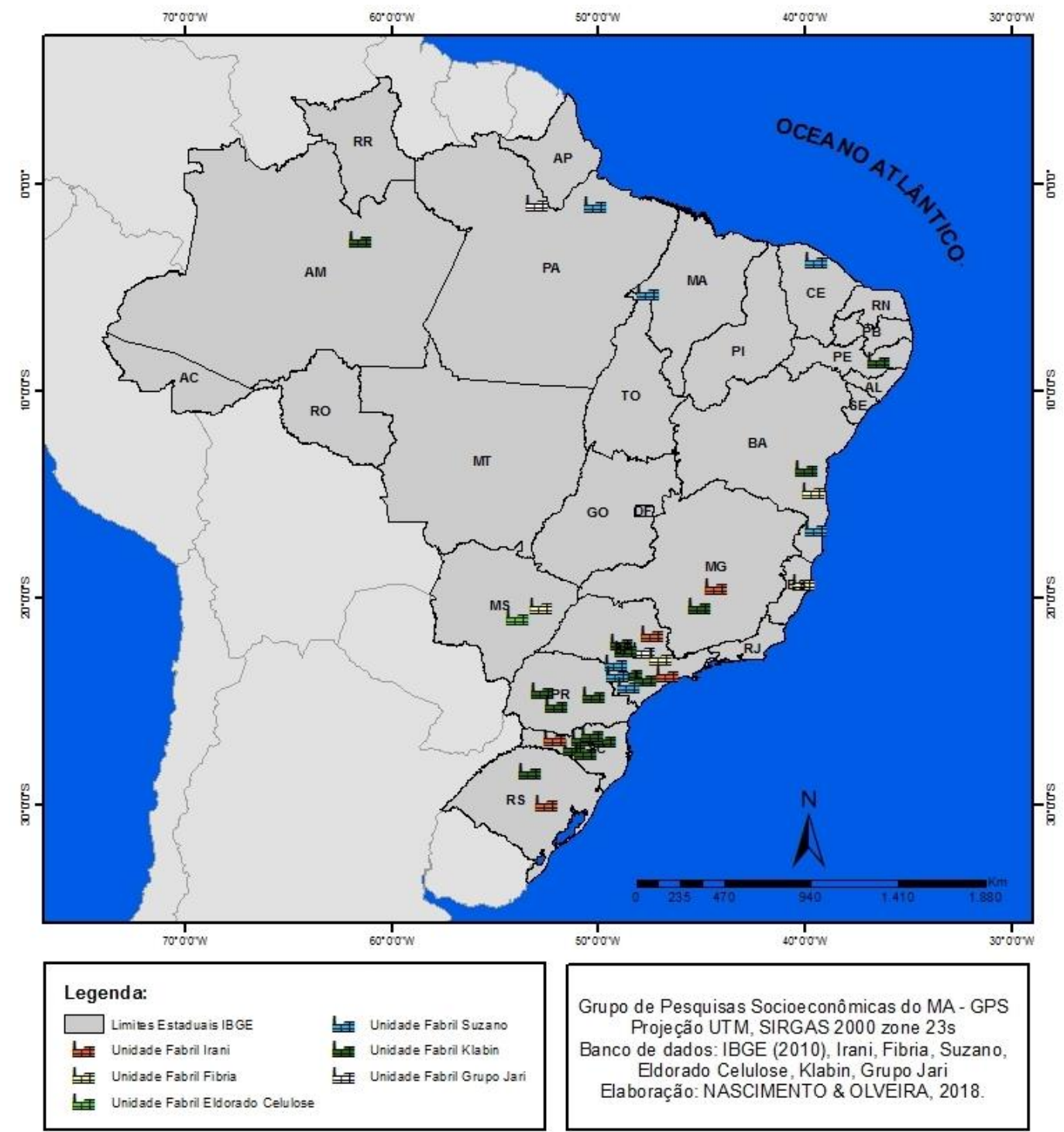

Fonte: Dados de pesquisa (2018)

Em suma, é na participação ativa do Estado, por meio de incentivos, que se ancora o crescimento da indústria de papel e celulose no Brasil. É também nesse modelo político de ações estatais em parcerias público-privadas que se tem o aprimoramento das culturas de eucalipto originário da Austrália - pronto para produzir em apenas sete anos - que se tornaria ao longo dos anos a principal matéria-prima de produção da cadeia de papel e celulose brasileira. Baseado num discurso desenvolvimentista de geração de emprego e renda, o Estado participa e sustenta os movimentos recentes de reestruturação produtiva da indústria de papel e celulose no Brasil. Um dos pontos mais visíveis dessa reestruturação é a desconcentração geográfica das regiões Sul e Sudeste, visando explorar novas áreas de fronteiras agrícolas no Norte e Nordeste do país. 
É nessa dinâmica de expansão de grandes conglomerados industriais de papel e celulose no Brasil que se tem, em 2009, o início da construção da mais nova unidade fabril da Suzano Papel e Celulose, no município de Imperatriz, estado do Maranhão.

\begin{abstract}
Em 2009, a empresa Pöyry deu início à implantação da sede da Suzano Papel e Celulose do município de Imperatriz, no estado do Maranhão, com a proposta de ser a maior planta industrial deste segmento no país. A duração da implantação inicial perdurou até o ano de 2015. Além da localização excepcional para o escoamento da produção pelo ramal ferroviário norte-sul até o porto do Itaqui, outros fatores espaciais também foram importantes no processo: a oferta de serviços urbanos para atender à demanda de mão de obra qualificada que residiria no município, a bacia hidrográfica do Tocantins-Araguaia, além de áreas extensas para o plantio de eucalipto no Maranhão, Piauí e Pará. (OLIVEIRA, 2018, p. 347).
\end{abstract}

A implantação industrial numa área amazônica vem consolidar os modelos históricos de reestruturação produtiva do Maranhão, baseados na concentração de capital pertencente a grandes grupos financeiros nacionais e internacionais voltados para a produção de commodities que necessitam de grandes frações de terra e água, seja na pecuária, metalurgia, soja ou na silvicultura do eucalipto.

Mesquita et al (2015) destacam que privilegiar o grande capital no processo de ocupação do território e inserção de modelos de crescimento econômico tornou-se uma constante na Amazônia Legal, sobretudo no Maranhão. Para os autores, o aumento da demanda do mercado mundial por commodities agrícolas e agroflorestais favoreceu as atividades do agronegócio, determinando o plantio intensivo de soja, dendê e eucalipto. Contudo, tais projetos visam à exportação de produtos primários agrícolas, por isso oferecem baixo retorno socioeconômico para o estado. 
Figura 3 - Contexto regional de implantação da unidade fabril da Suzano no Maranhão

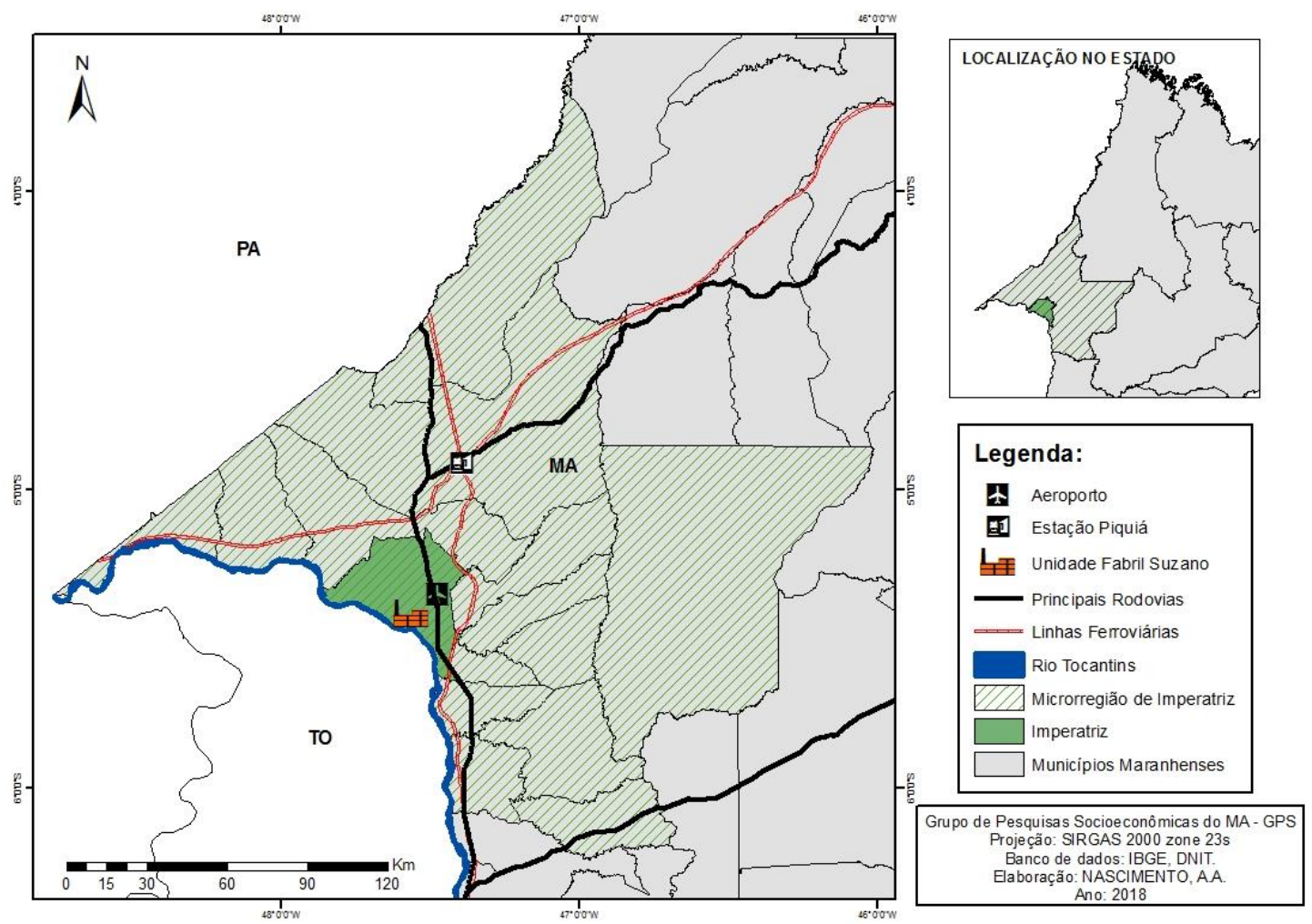

Fonte: Dados de pesquisa (2018)

No processo de territorialização da produção econômica, a nova unidade fabril do conglomerado Suzano Papel e Celulose desencadeou a expansão de sua cadeia produtiva no Maranhão, o que tem proporcionado um modelo de integração produtiva com toda a faixa oriental da Amazônia Legal, como discutiremos na seção a seguir.

\section{Cadeia produtiva do papel e celulose e sua dinâmica no Maranhão}

A indústria brasileira de celulose compõe-se das empresas que produzem celulose e pasta de alto rendimento. Essa polpa pode ser vendida nos mercados doméstico e externo (sendo chamada de celulose de mercado) ou ser usada na produção de papel pela própria empresa que a produz (nesse caso, a polpa é chamada de celulose de integração). Já a indústria de papéis compreende as empresas produtoras de papéis assim classificados: papéis de imprensa, de imprimir e escrever, de embalagem, sanitários, cartão e para outros fins.

Tal atividade industrial tem como característica principal uma estrutura baseada em economia de enclave, ou seja, em um modelo econômico de mercado globalizado no qual as atividades produtivas localizadas em regiões periféricas 
destinam sua produção quase que essencialmente para a exportação, sem integração com o mercado local. Mediante a sua atividade e o volume de produção, necessita basicamente de dois elementos espaciais fundamentais: terra barata e potencial hidrológico em abundância.

Figura 4 - Potencial hidrológico do sudoeste maranhense e a unidade da Suzano

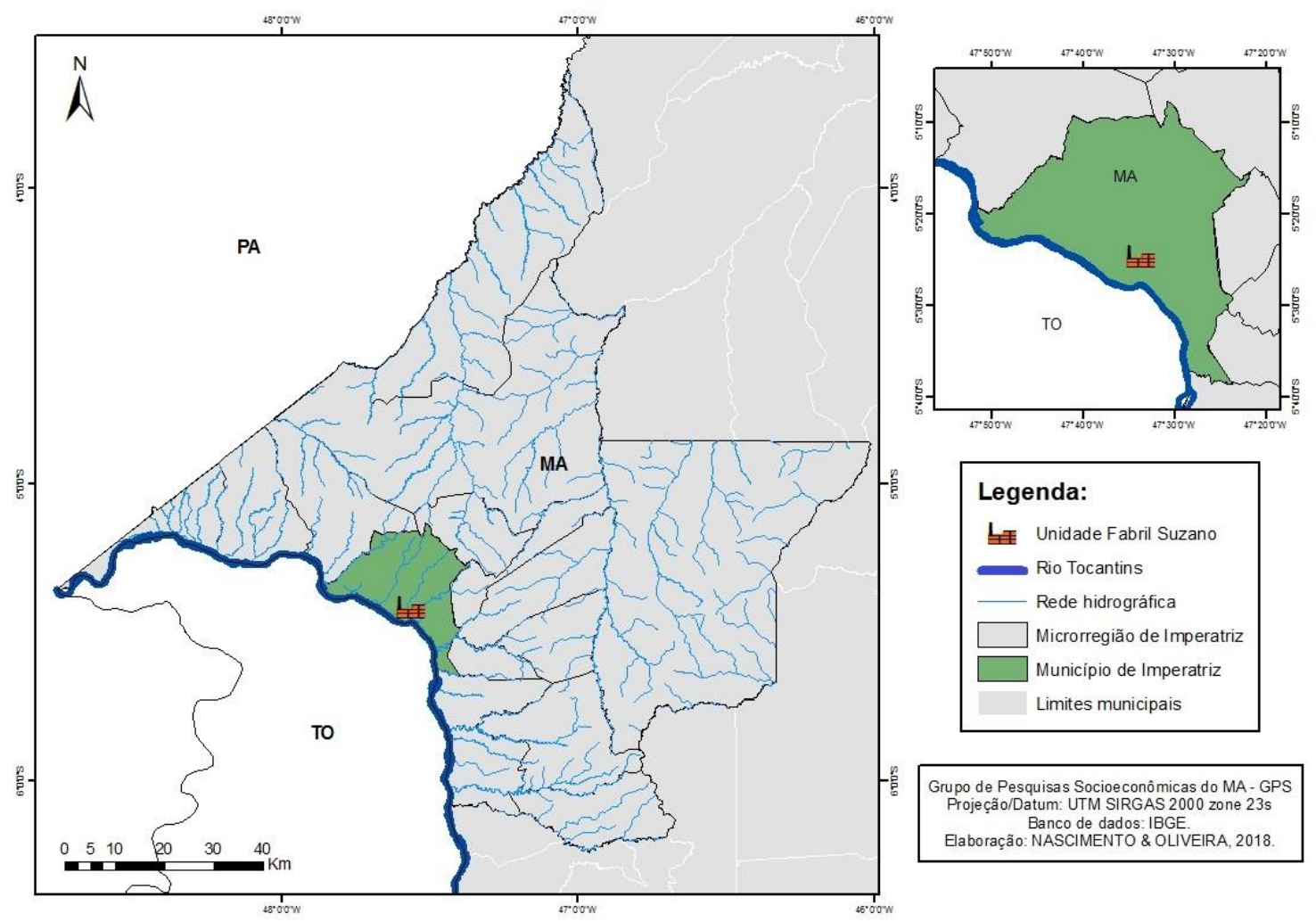

Fonte: Dados da pesquisa (2018)

Como os históricos modelos econômicos desenvolvidos no Maranhão implicam a disponibilidade de grandes porções de terra barata e água, destaca-se que Imperatriz, sede da unidade fabril da Suzano, preenche esses requisitos. A cidade é banhada pelo rio Tocantins, pertencente à bacia hidrográfica do TocantinsAraguaia, cujo potencial hidrológico - considerado a partir do rio principal e suas ramificações entre riachos, outros pequenos rios e água subterrânea - permite o avanço do cultivo do eucalipto como matéria-prima base da cadeia de papel e celulose, conforme visto na Figura 4.

É importante frisar que a cadeia produtiva industrial é composta por etapas consecutivas de transformação de diversos insumos até chegar ao produto final. Além dos insumos básicos, inclui a matéria-prima, máquinas e equipamentos, distribuição, prestadores de serviços, até chegar aos consumidores. Dessa forma, a 
indústria de papel e celulose inicia seu processo de produção no plantio do eucalipto, seguido da colheita, na etapa de extração florestal.

Denomina-se setor de celulose e papel o conjunto formado pelas seguintes indústrias: de celulose, de papéis e de artefatos de papéis. Essas três indústrias em conjunto e mais as bases de plantio, a indústria gráfica e ainda os segmentos distribuidores vinculados àquelas indústrias constituem a cadeia produtiva da celulose e papel, esquematizada na Figura 5.

A Figura 5 apresenta a cadeia produtiva de papel e celulose considerando sua dinâmica de funcionamento no estado do Maranhão, a partir da implantação da Suzano Papel e Celulose em Imperatriz. A cadeia abrange as etapas de produção de madeira, energia, celulose e papel, reciclagem de papel, produção gráfica e editorial e também atividades de comércio, distribuição e transporte.

Essa cadeia inicia-se com a Pesquisa e Desenvolvimento (P\&D) de árvores que são selecionadas para o plantio, de modo a favorecer o crescimento e a produção de celulose; depois as mudas melhor adaptáveis são reproduzidas em viveiros até 120 dias depois de brotarem. Após a preparação das mudas, elas são direcionadas para as áreas de plantio coordenadas por equipes especializadas na silvicultura.

Especificamente no Maranhão, a dinâmica de plantio tem sido feita de três formas: a) em terras compradas pela própria Suzano; b) em terras arrendadas pelos proprietários para que a empresa produza; e c) em terras autônomas onde os proprietários produzem e vendem seu próprio eucalipto cultivado a partir de mudas fornecidas pela Suzano. É importante frisar que nessa última dinâmica há uma relação monopsonista, uma vez que a Suzano é a única compradora de eucalipto da região, pois as indústrias de ferro-gusa possuem suas próprias áreas cultivadas e utilizam outras fontes de energia em suas caldeiras. 
Figura 5 - Cadeia produtiva de papel e celulose no Maranhão

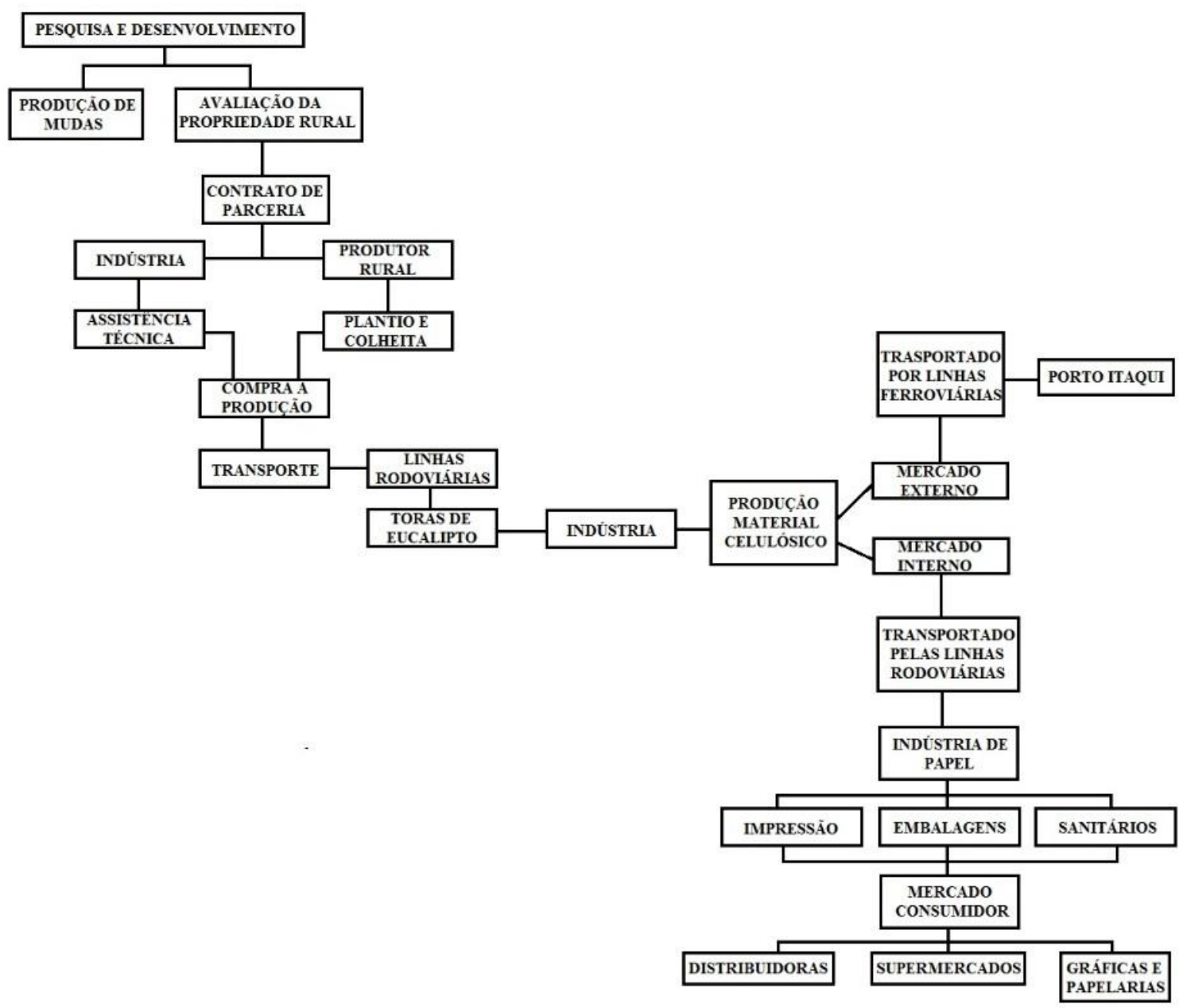

Fonte: Oliveira (2018)

Após o plantio das mudas, que atualmente levam de 6 a 7 anos para chegar ao estágio de corte, inicia-se a etapa da colheita e do transporte. Nela, a cadeia tem um alto valor agregado devido à inserção de maquinário para corte, lixamento e retirada, além de caminhões para transporte e todas as empresas fornecedoras de peças e equipamentos. O corte é feito utilizando-se máquinas feller buncher e haverster, que descascam o eucalipto e o cortam em toras de 6 metros, transportadas até a fábrica em caminhões tritrem (Figura 6). Cada caminhão leva em média 50 toneladas. 
Figura 6 - Caminhão de eucalipto passando pela BR-010, no trecho da cidade de Imperatriz
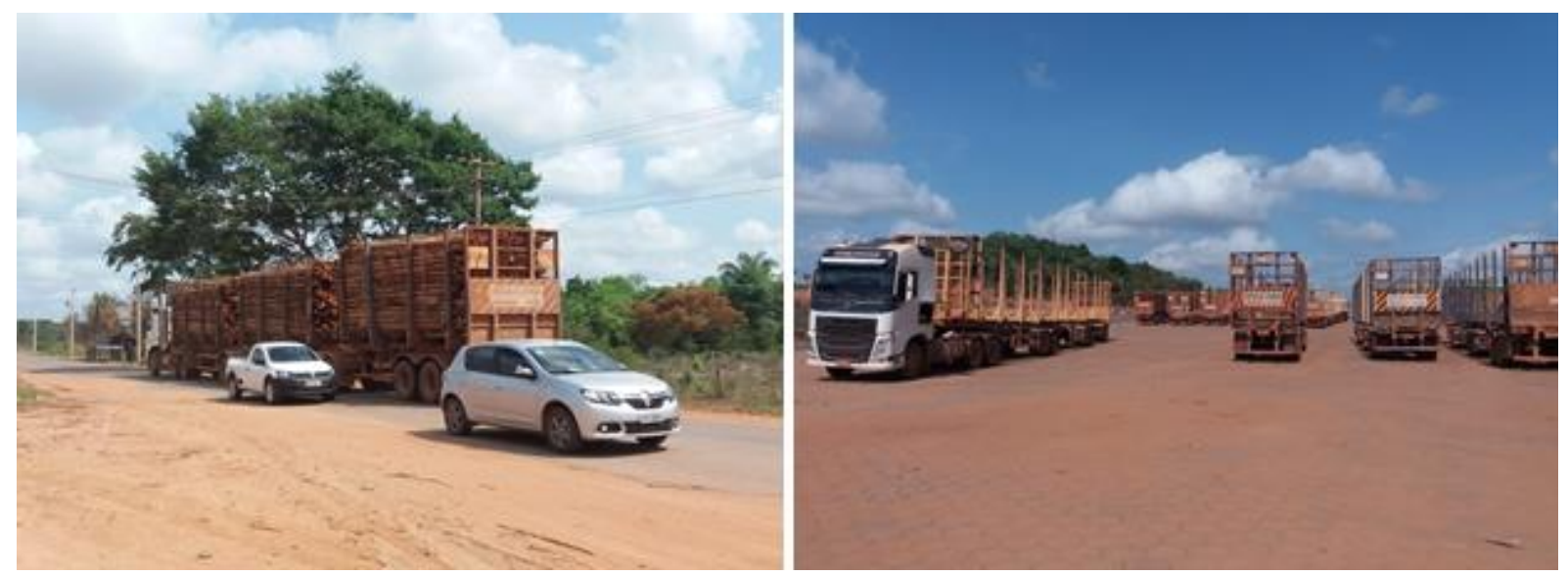

Fonte: Dados da pesquisa (2018)

O eucalipto levado até a fábrica pelo modal rodoviário é transformado em pasta de celulose, que é destinada quase que exclusivamente para o mercado externo. A pasta é transportada via terminal ferroviário, modal construído pela própria empresa (Figura 7), que sai diretamente da fábrica e segue até o terminal do Pequiá, na cidade de Açailândia, conectando-se, posteriormente, ao terminal ferroviário norte-sul, que transporta a pasta de celulose para o Porto do Itaqui.

\section{Figura 7 - Transporte de pasta de celulose da unidade fabril da Suzano no município de Imperatriz}
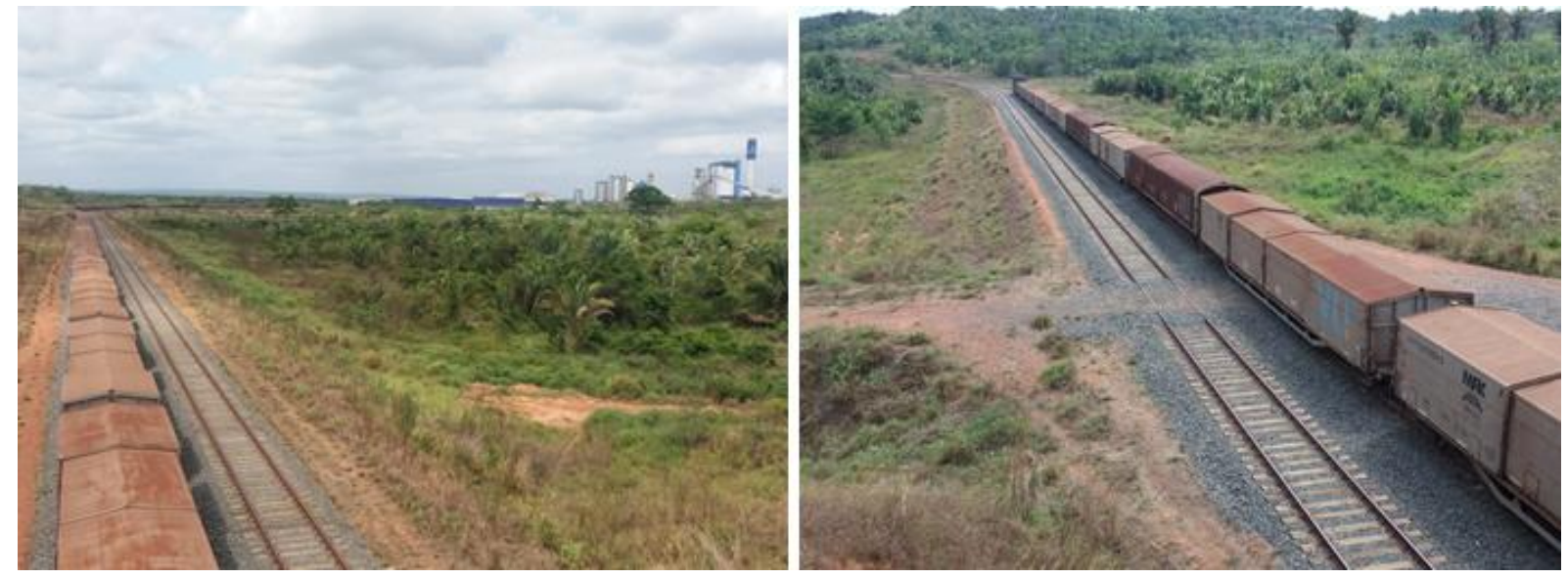

Fonte: Dados da pesquisa (2018)

A pequena parcela de pasta de celulose que não é vendida para o comércio externo, é utilizada pela própria fábrica na fabricação de papel higiênico, papel toalha e guardanapo. A fábrica produtora de papel da Suzano foi construída internamente no final de 2016. Também fornece pasta de celulose para outras 
indústrias do segmento, embora em pequeno percentual comparado ao total de sua produção.

\section{O avanço da fronteira agrícola da silvicultura do eucalipto na Amazônia maranhense}

Devido às suas particularidades e multiplicidades geográficas, o Maranhão tem importante papel enquanto estado de transição entre o Norte e o Nordeste do Brasil. Nesse sentido historicamente, recebeu atenção de políticas de desenvolvimento regional de duas frentes: da Superintendência de Desenvolvimento da Amazônia (Sudam) e da Superintendência de Desenvolvimento do Nordeste (Sudene).

Há, nesse contexto, a inserção e consolidação de um padrão de desenvolvimento regional no estado, sobretudo a partir do século $\mathrm{XX}$, fundamentado em projetos de reestruturação produtiva promovidos por políticas estatais direcionadas para a atração e implantação de grandes projetos industriais de "integração regional" econômica da Amazônia Legal. Exemplos desses projetos são os mínero-exportadores, como a Alumar, em São Luís, e o complexo industrial de ferro-gusa, em Açailândia; e os agroindustriais, como a Maity Bioenergia, em Estreito, Algar em Porto Franco, e, mais recentemente, a Suzano Papel e Celulose em Imperatriz.

Sobre esse processo e o de integração industrial da Amazônia, Pantoja e Pereira (2016) e Oliveira et al (2018) destacam que desde a década de 1980, com o Projeto Grande Carajás, já se preparava toda a estrutura para a implementação de novas indústrias na região. É possível observar que, desde aquele período, a construção da Estrada de Ferro Carajás, ligando a província mineral de Carajás, no sudeste do Pará, ao Complexo Portuário de São Luís (portos do Itaqui e de Ponta da Madeira), no litoral maranhense, já visava a um propósito de expansão industrial.

Tal fato está diretamente ligado à existência da ALUMAR, beneficiadora do mineral extraído, e sua influência no surgimento de oito usinas de processamento de ferro gusa às margens dessa estrada de ferro. Por sua vez, a atividade de processamento de gusa é vinculada à produção de madeira, que foi estimulada pelo projeto CELMAR, em Imperatriz, em 1992. Toda essa estrutura de transporte para o porto e fornecimento de matériaprima sinalizam a própria condição de implementação da Suzano em Imperatriz, cuja presença no estado do Maranhão remonta a meados da década de 1980, quando iniciaram as primeiras experiências no Maranhão com a plantação de eucalipto no leste maranhense, no município de Urbano Santos. (OLIVEIRA et al, 2018, p. 142). 
Ao fim da década de 1990, a conjuntura política que permeou a implantação do complexo minerário estimulou o estabelecimento de projetos no Maranhão e em toda a Amazônia Legal em moldes correspondentes à economia de enclave, voltada para a produção de commodities para exportação e com pouca conexão socioeconômica local. Exemplos disso são o agronegócio, representado pelo plantio extensivo da soja, e a atividade agroflorestal centrada no eucalipto, que se consolidaram e expandiram as fronteiras econômicas do Maranhão. Isso porque, apesar de seu caráter extensivo, o cultivo da soja e do eucalipto ocorreu em diferentes áreas geográficas e contribuiu bem mais para a ampliação dos "fronts" econômicos do que a expansão decorrente da pecuária extensiva (MESQUITA et al, 2015).

Empreendimentos de soja e, mais especificamente, de eucalipto têm tipificado e acentuado transformações no Maranhão a partir de sua consolidação enquanto fronteira agrícola na Amazônia Legal à medida que grandes espaços têm sido direcionados para a produção de commodities agrícolas e agroflorestais cujas consequências são concentração de renda em grupos de capital nacional e estrangeiro e baixo retorno socioeconômico local.

$O$ avanço da produção agroflorestal tem promovido tipificações em microrregiões específicas, especialmente próximas aos limites da Amazônia Legal. $E$, como consequência, além dos impactos socioambientais (que não se pretende discutir em profundidade neste trabalho), está-se constituindo uma nova fronteira agrícola na Amazônia Legal, como podemos perceber na Figura 8, que expressa 0 avanço de áreas com plantio de eucalipto entre o Maranhão, Pará e Tocantins. 
Figura 8 - Municípios produtores de eucalipto em áreas de fronteira entre Maranhão, Pará e Tocantins

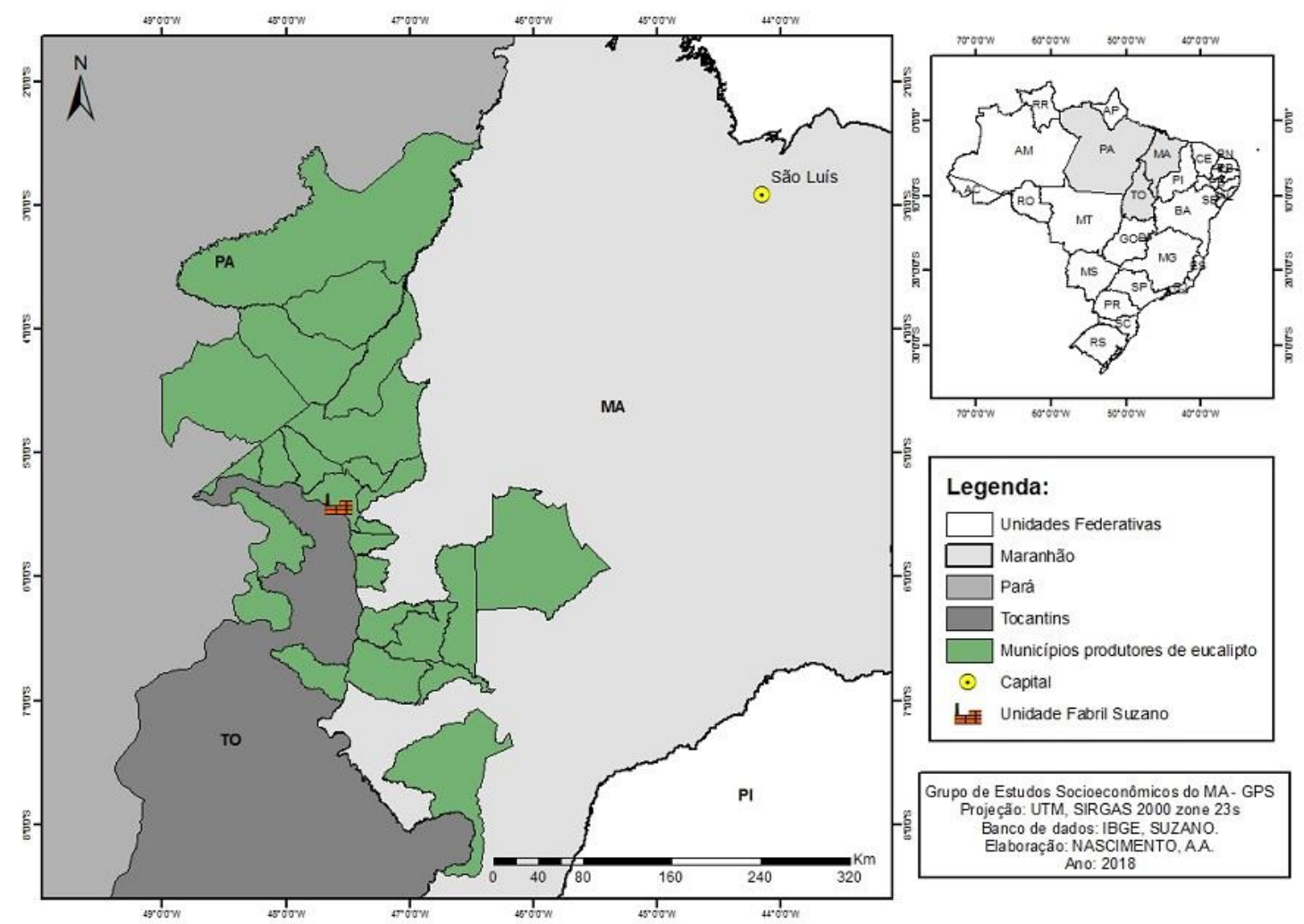

Fonte: Dados da pesquisa (2018)

Observa-se que todos os municípios produtores ficam próximos à unidade industrial. Esse modelo de logística de matéria-prima próxima à área de produção é adotado por todas as indústrias de transformação de base química para obtenção de material celulósico, diferentemente das indústrias de produção de papel, que não precisam estar próximas das áreas de extração. Esses municípios são denominados núcleos de abastecimento. No Pará está o núcleo de Dom Eliseu, composto pelos municípios de Paragominas, Ulianópolis e Dom Eliseu, e, no Maranhão, o núcleo de Cidelândia, composto por Porto Franco, Imperatriz, Cidelândia, Açailândia e Bom Jesus das Selvas, conforme Quadro 1 abaixo.

\section{Quadro 1 - Relação dos principais municípios produtores de eucalipto nos estados do PA, TO e MA}

\begin{tabular}{|l|l|l|l|}
\hline \multicolumn{1}{|c|}{ Pará } & \multicolumn{2}{c|}{ Maranhão } & \multicolumn{1}{c|}{ Tocantins } \\
\hline Paragominas & Itinga do MA & Imperatriz & Araguatins \\
\hline Ulianópolis & Bom Jardim & Porto Franco & Ananás \\
\hline Dom Eliseu & Bom Jesus das Selvas & Estreito & Darcinópolis \\
\hline Rondon do Pará & Açailândia & Carolina & $\begin{array}{l}\text { São Miguel do } \\
\text { Tocantins }\end{array}$ \\
\hline Itinga do PA & $\begin{array}{l}\text { São Pedro da água } \\
\text { Branca }\end{array}$ & Cidelândia & $\begin{array}{l}\text { Sítio Novo do } \\
\text { Tocantins }\end{array}$ \\
\hline
\end{tabular}

Fonte: Dados da pesquisa a partir de IBGE (2017) 
Embora o número de municípios seja um pouco maior, o quadro apresenta o quantitativo dos principais municípios produtores listados oficialmente como áreas de plantio de eucalipto, contudo acredita-se que extraoficialmente essa quantidade seja maior. O uso de recursos naturais e o uso da terra são destinados em grandes áreas para a produção de papel e celulose. E à medida que o espaço é produzido para atender à ordem econômica hegemônica, a paisagem vai sendo modificada. Há, dessa forma, uma verdadeira territorialização agroflorestal no estado do Maranhão, consolidando a Amazônia Legal nas fronteiras agrícolas contemporâneas do Brasil.

Figura 9 - Monocultura do eucalipto na microrregião de Imperatriz

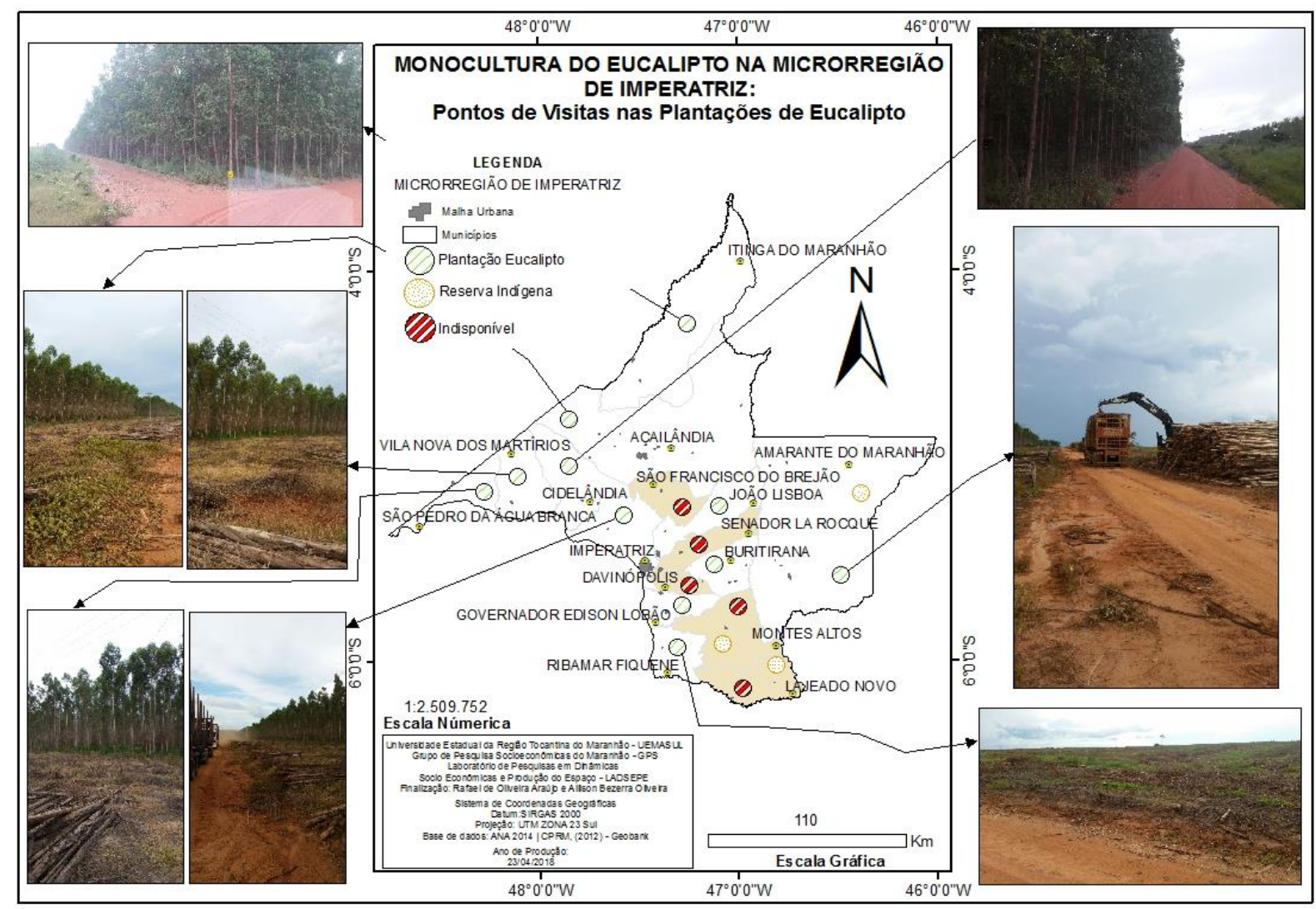

Fonte: Dados da pesquisa (2018)

Quando se observa o espaço maranhense sob a perspectiva dos "fronts de desenvolvimento", visualizando-o num contexto de estados da Amazônia brasileira, como o Maranhão, Pará e o Tocantins, percebe-se o avanço desse modelo de produção no país, como expresso no Gráfico 1 abaixo. Com exceção do Pará, em que houve uma diminuição - fruto de políticas ambientais e do aumento de áreas em outros estados, como o próprio Tocantins e Maranhão - houve aumento expressivo nas áreas plantadas, o Estado do Tocantins passou de 47.542 milhões de hectares 
em 2010 para 116.798 em 2016, o Maranhão de 151.403 para 221.859 milhões de hectares no mesmo período.

\section{Gráfico 1 - Avanço do eucalipto no Pará, Maranhão e Tocantins (2010 a 2016)}

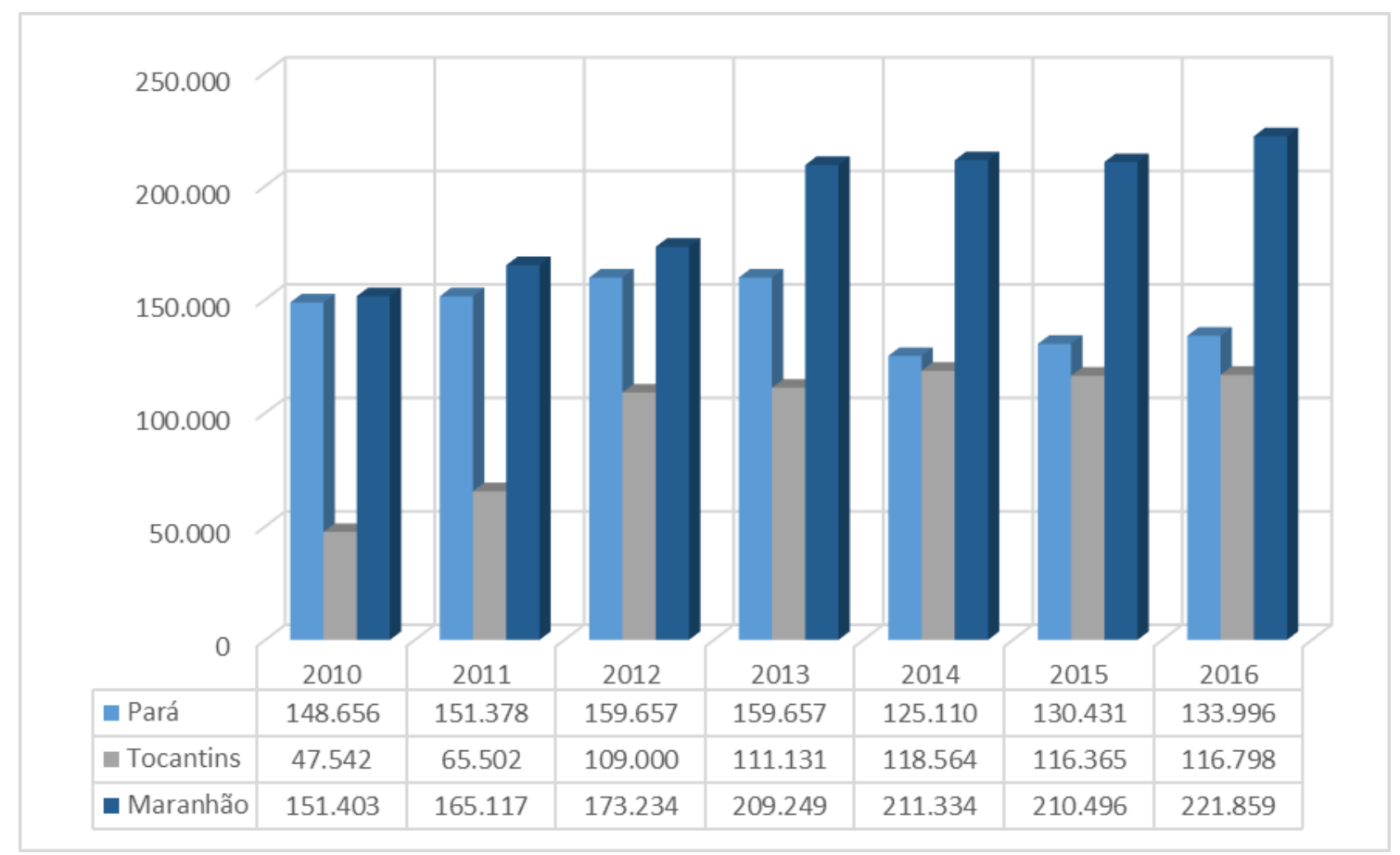

Fonte: Indústria Brasileira de Árvores (2017) e Instituto Brasileiro de Geografia e Estatística (2017)

O aumento das áreas plantadas constitui-se em novos e constantes processos de territorialização de novas fronteiras agrícolas em regiões periféricas pelos grandes conglomerados agroindustriais pautados em políticas estatais de desenvolvimento. Esta expansão integra-se com os transportes, que contribuem para o processo de territorialização e consequente transformação local e permitem a reprodução do capital em sinergia com os objetivos pautados. Os transportes assumem, portanto, papel fundamental nesse processo, à proporção que encurtam as distâncias. A capacidade para movimentar os produtos define a mobilidade do capital sob a forma de mercadoria. E essa mobilidade depende das relações de transporte modificadas pelos atributos das mercadorias, como peso, tamanho, fragilidade, mercado consumidor, perecibilidade etc. (HARVEY, 2005, 2013).

Como qualquer outro insumo intermediário, o valor da mercadoria "mudança de localização" entra no preço de custo de outras mercadorias. Por isso, o valor de todas as mercadorias inclui todos os custos socialmente necessários de transporte, definidos como o custo médio de levar os produtos a seus destinos. O custo do movimento não é a única consideração. A regularidade e a confiabilidade dos fluxos do transporte podem reduzir a necessidade de estoques tanto das matérias-primas quanto dos produtos acabados e, portanto, liberar o capital "ocioso" para a acumulação ativa. A continuidade na circulação do capital só pode ser assegurada mediante a criação de um sistema de transporte eficiente e 
espacialmente integrado, organizado em torno de alguma hierarquia dos centros urbanos. A velocidade do movimento também é fundamental. A "distância espacial" então se reduz ao tempo porque "não depende, por exemplo, da distância espacial do mercado, mas da velocidade - do quantum de tempo em que se chega ao mercado". (HARVEY, 2013, p. 550$551)$.

A mobilidade do capital na forma de mercadoria é realizada dentro de uma estrutura em eterna modificação dos espaços relativos, pois o custo e o tempo podem ser alterados pelo desenvolvimento dos meios de transporte, relativizando as distâncias geográficas. Na Figura 10, abaixo, nota-se a intrínseca relação entre a disposição geográfica das fazendas e a localização das rodovias para o escoamento do eucalipto. Onipresente em grandes quantidades de fazendas e áreas de produção, a matéria-prima circula livremente e de modo veloz através de rodovias federais e estaduais, contribuindo não só para a especialização produtiva do território, mas também para a rapidez de produção e consequente reprodução do capital.

Figura 10 - Transporte e avanço de áreas de produção de eucalipto no Maranhão e Pará

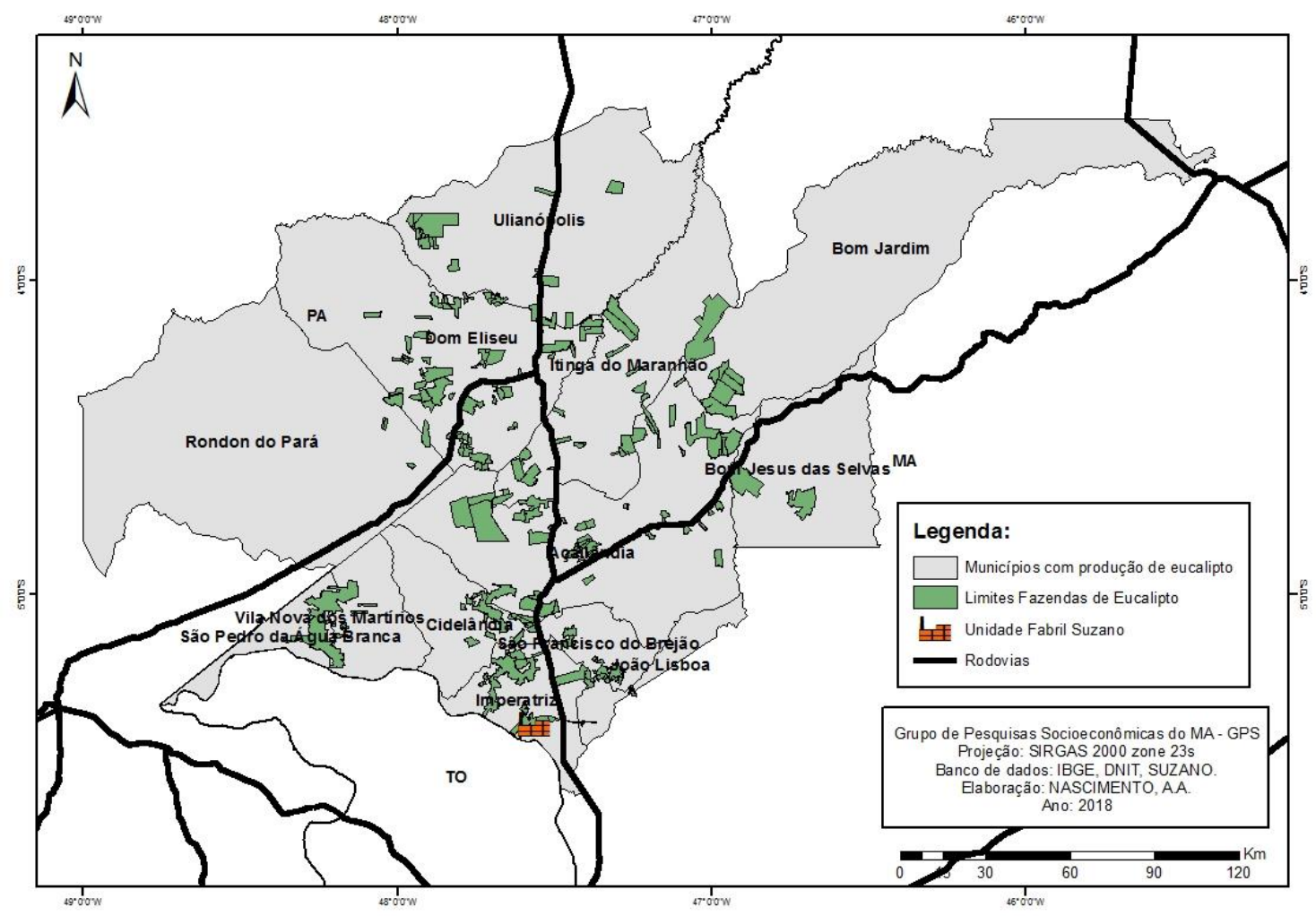

Fonte: O autor com base em dados do IBGE, DNIT e Suzano (2018)

A integração entre as infraestruturas de transportes e as áreas de cultivo de eucalipto faz parte do processo histórico de formação socioeconômica do Maranhão e da Amazônia Legal e se reflete no avanço das redes técnicas nesses territórios. A 
parceria estatal com o grande capital industrial subjaz os ciclos de reestruturação produtiva e de desenvolvimento econômico baseados em grandes projetos.

Os investimentos públicos diretos vêm sendo alocados em um conjunto de obras públicas relacionadas à infraestrutura, particularmente na área de energia elétrica (geração e transmissão), logística e construção de estradas. Indiretamente, o Estado também vem atuando via empresas estatais e sistema estatal de financiamento. Do lado da iniciativa privada, em termos gerais, os investimentos passam pela logística, implantação de indústrias e expansão da área de atuação nos diferentes complexos que operam na Amazônia. Por exemplo, algumas iniciativas já em andamento e outras anunciadas têm especificidades que mudam de atividade para atividade. No complexo mineral, os investimentos vão nessa direção (guseiras, aciarias, cimento e calcário); no complexo celulose (plantio de floresta, fábricas), na logística (duplicação de ferrovias, construção e ampliação de complexos portuários), no complexo da soja (compra de terras, ampliação de áreas, indústrias de beneficiamento). [...] As fontes de financiamentos são diversas, inclusive estatais (BNDES), mas também próprias, de bancos e fundos de investimentos. Vale, Petrobras, Suzano, Agropalma e Bung Cargill são algumas das grandes empresas presentes nesse cenário atual da Amazônia. (MESQUITA et al, 2015, p. 284).

Nesse contexto, a Suzano Papel e Celulose, instalada em Imperatriz construiu um ramal ferroviário interligando diretamente sua fábrica ao ponto de conexão mais próximo, neste caso, o de Pequiá, no município de Açailândia (Figura 11).

\section{Figura 11 - Modal rodoviário da fábrica da Suzano até o porto do Itaqui}

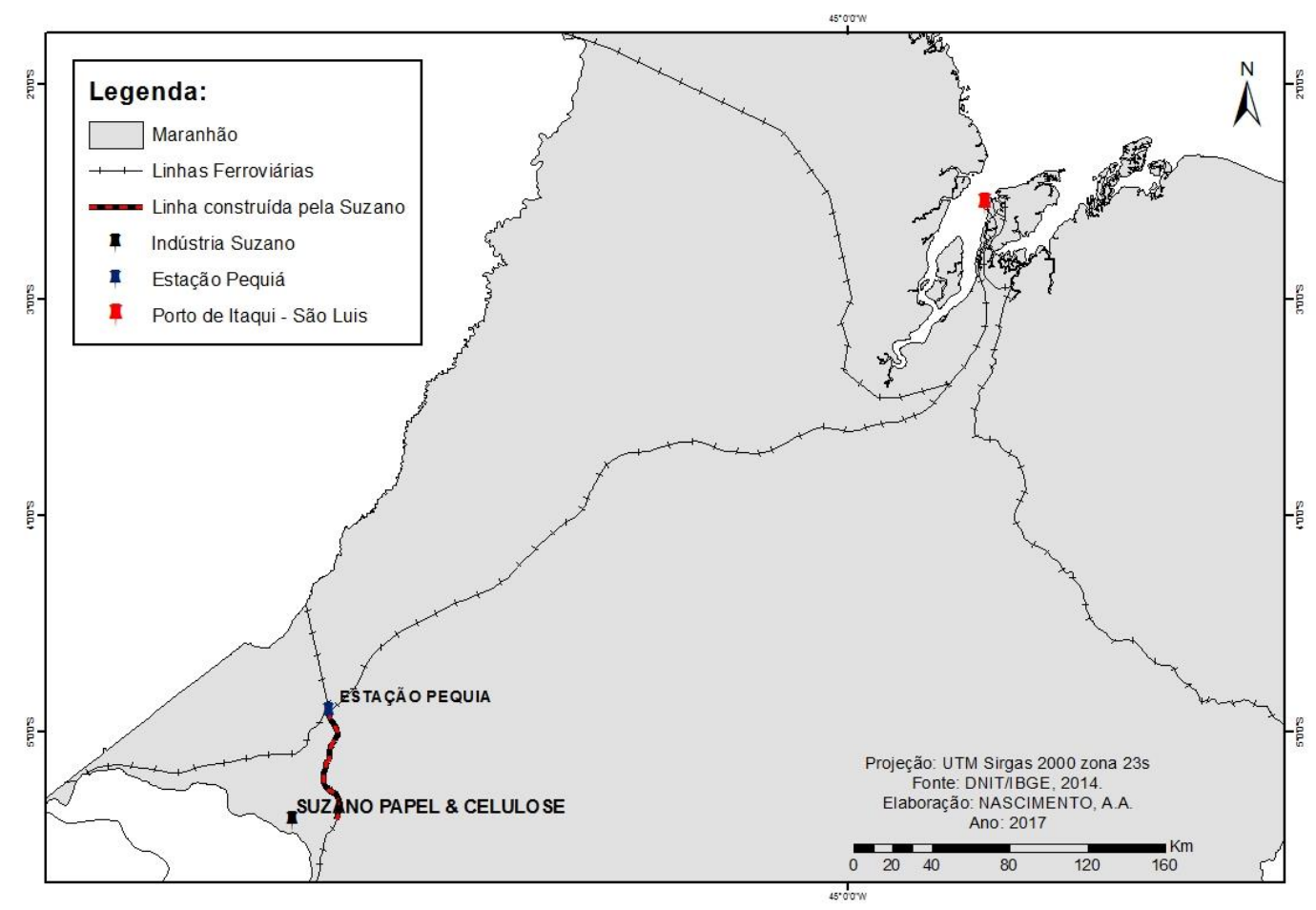

Fonte: Dados da pesquisa (2017)

Tal conexão, em destaque na figura acima, permite que a celulose fabricada e direcionada ao mercado externo siga de modo mais rápido e barato até o Porto do Itaqui, em São Luís, capital do estado. Representa velhas e novas contradições do 
processo de mobilidade do capital na Amazônia Legal frente aos processos históricos de desenvolvimento destinados a esse território.

\section{Considerações finais}

O avanço atual da silvicultura do eucalipto (parte integrante da cadeia produtiva de papel e celulose), impulsionado pela implantação da Suzano Papel e Celulose no município de Imperatriz, reproduz o modelo histórico baseado em economias de enclave na Amazônia Legal brasileira. Em outras palavras, ele se traduz em um modelo econômico baseado na pilhagem de recursos naturais e acumulação de capital por grandes grupos de capital nacional e/ou internacional que têm como foco a produção de commodities para o mercado externo, com enorme ônus do ponto de vista ambiental e pouco retorno socioeconômico local.

Esse modelo econômico, com forte ação estatal, tem uma compreensão de progresso que passa pela ideia de reprodução ilimitada de recursos, parte importante da cadeia produtiva global. Nessa cadeia as etapas mais onerosas de recursos naturais voltadas para o beneficiamento de matéria-prima são destinadas aos países periféricos, como o Brasil.

$\mathrm{Na}$ consolidação de sua economia agro-mínero-exportadora, o estado do Maranhão insere sua participação na Amazônia Legal como uma das mais importantes fronteiras agrícolas do país. No bojo da constituição dessa fronteira agrícola (ou economia de fronteira), há uma cooperação de fato, a partir dos processos de "integração" regionais com as redes técnicas de transportes que permitem que o capital se reproduza em maior velocidade.

Nesse sentido, não apenas os recursos naturais, como também os modais de transporte estaduais são convidados a atuar em conjunto numa concepção de progresso, desenvolvimento e crescimento baseada no paradigma sociedadenatureza, em que a acumulação de capital infinita é acompanhada da extração de recursos naturais tidos como infinitos.

\section{REFERÊNCIAS}

BECKER, B. K. Amazônia: geopolítica na virada do III milênio. Rio de Janeiro: Garamond, 2007.

BECKER, B. K. Geopolítica da Amazônia. Revista Estudos Avançados, São Paulo, v. 19, n. 53, p. 71-86, 2005. 
BECKER, B. K. Revisão das políticas de ocupação da Amazônia: é possível identificar modelos para projetar cenários? Parc. Estrat., Brasília-DF, v. 6, n. 12, p. 135-159, set. 2001.

BECKER, B. K. Fronteira e urbanização repensadas. R. Bras. Geogr., Rio de Janeiro, v. 36, n. 2, p. 357-371, 1985.

BECKER, B. K. Os eixos de integração e desenvolvimento e a Amazônia. Revista Território, Rio de Janeiro, v. 4, n. 6, p. 29-42, jan./jun. 1999.

CANO, W. Desconcentração produtiva regional do Brasil: 1970-2005. São Paulo: Editora Unesp, 2007a.

CANO, W. Desequilíbrios regionais e concentração industrial no Brasil: 1930-1970. 3. ed. São Paulo: Editora Unesp, 2007b.

CANO, W. Raízes da concentração industrial em São Paulo. 2. ed. São Paulo: T.A. Queiroz,1986.

DNIT. Departamento Nacional de Infraestruturas de transportes. Mapa rodoviário do Maranhão e Pará. Brasília, 2018. Disponível em: <http://www.dnit.gov.br/>. Acesso em: 23 de setembro de 2018.

HARVEY, D. A produção capitalista do espaço. São Paulo: Annablume, 2005.

HARVEY, D. Os limites do capital. São Paulo: Boitempo, 2013.

IBÁ. Indústria Brasileira de Árvores. Relatório de produção da Silvicultura no Brasil. São Paulo, 2017. Disponível em: <https://www.iba.org/>. Acesso em: 10 de julho de 2018.

IBGE. Instituto Brasileiro de Geografia e Estatística. Produção Extrativista e da Silvicultura no Brasil, 2017. Disponível em: <https://www.ibge.gov.br/>. Acesso em: 14 de julho de 2018.

MESQUITA, B. A. de. et al Formação socioeconômica do estado do Maranhão. In: CASTRO, E. R. de.; CAMPOS, I. (org.) Formação socioeconômica da Amazônia. Belém: NAEA/UFPA, 2015.

OLIVEIRA, A. B. et al Cadeia produtiva de papel e celulose e transformações recentes no sudoeste maranhense. Revista Interespaço, Grajaú, v. 4, n. 12, p.135-154, jan. 2018.

OLIVEIRA, A. B. implantação industrial, reestruturação produtiva e alterações no mercado de trabalho no sudoeste maranhense (2008-2018). In: SANTOS, L. C.; SEABRA, G. F.; CASTRO, C. E. (org.). Geografia: trabalho, sociedade e meio ambiente. São Luís: Eduema, 2018. p. 340-360.

OLIVEIRA, A. B.; NASCIMENTO, A. A. Atores e impactos na reestruturação do espaço urbano de Imperatriz-MA: observações a partir da implantação da Suzano Papel e Celulose (2008-2015). Espaço e Economia, ano VII, n. 13, p. 154-171, 2018.

PANTOJA, V. M. L.; PEREIRA, J. M. Grandes projetos e populações tradicionais na Amazônia: a Suzano Papel e Celulose no Maranhão. Política \&Trabalho, João Pessoa, n. 45, p. 327-340, jul./dez. 2016.

PERPETUA, G. M. et al. Estratégias de territorialização das corporações agroextrativistas na América Latina: o caso da indústria de celulose no Brasil. Revista NERA, Presidente Prudente, ano 20, n. 40, p. 61-87, set./dez. 2017. 
SODRÉ, R.; RAMIRES, J. C. de L. Os papéis urbanos da cidade de Carolina na fronteira agrícola da Amazônia Legal. Revista Interespaço, Grajaú, v. 4, n. 14, p.145-167, maio/ago. 2018.

SMITH, N. Desenvolvimento desigual. Rio de Janeiro: Bertrand, 1988.

SUZIGAN, W. Indústria brasileira: origem e desenvolvimento. São Paulo: Hucitec; Campinas: Editora da Unicamp, 2000.

\section{NOTAS DE AUTOR}

\section{CONTRIBUIÇÃO DE AUTORIA}

Allison Bezerra Oliveira - Concepção. Coleta de dados, Análise de dados, Elaboração do manuscrito, revisão e aprovação da versão final do trabalho.

\section{FINANCIAMENTO}

Artigo resultante do projeto de pesquisa "Especialização produtiva e uso competitivo do território no sudoeste maranhense pela cadeia de papel e celulose: técnica, terra e trabalho" desenvolvido com auxílio financeiro concedido através do Edital no 002/2018 - UNIVERSAL via Fundação de Amparo à Pesquisa e ao Desenvolvimento Científico e Tecnológico do Maranhão - FAPEMA.

\section{CONSENTIMENTO DE USO DE IMAGEM}

Não se aplica.

\section{APROVAÇÃO DE COMITÊ DE ÉTICA EM PESQUISA}

Não se aplica.

\section{CONFLITO DE INTERESSES}

Não se aplica.

\section{LICENÇA DE}

Este artigo está licenciado sob a Licença Creative Commons CC-BY. Com essa licença você pode compartilhar, adaptar, criar para qualquer fim, desde que atribua a autoria da obra.

\section{HISTÒRICO}

Recebido em: 08-01-2019

Aprovado em: 05-02-2019 